\title{
Characterization of cardiopulmonary function and cardiac muscarinic and adrenergic receptor density adaptation in C57BL/6 mice with chronic Trypanosoma cruzi infection
}

\author{
N. N. ROCHA ${ }^{1,3}$, S. GARCIA ${ }^{1,2}$, L. E. D. GIMÉNEZ ${ }^{1}$, C. C. Q. HERNÁNDEZ ${ }^{1}$, J. F. V. SENRA ${ }^{2}$, \\ R. S. LIMA ${ }^{2}$, F. CYRINO ${ }^{4}$, E. BOUSKELA ${ }^{4}$, M. B. P. SOARES ${ }^{2}$, R. RIBEIRO DOS SANTOS ${ }^{2}$ \\ and A. C. CAMPOS DE CARVALHO ${ }^{1 *}$ \\ ${ }^{1}$ Instituto de Biofísica Carlos Chagas Filho, Universidade Federal do Rio de Faneiro, Rio de Faneiro, Brazil \\ ${ }^{2}$ Centro de Pesquisas Gonçalo Moniz, Fundação Oswaldo Cruz, Salvador, Bahia, Brazil \\ ${ }^{3}$ Universidade Federal Fluminense, Niterói, Rio de Faneiro, Brazil \\ ${ }^{4}$ Universidade do Estado do Rio de Faneiro, Rio de Faneiro, Brazil
}

(Received 30 March 2006; revised 10 Fune 2006; accepted 13 Fune 2006; first published online 18 September 2006)

\begin{abstract}
SUMMARY
Circulating antibodies in chagasic patients interact with myocardial $\beta$ adrenergic and muscarinic cholinergic receptors, triggering intracellular signals that alter cardiac function along the course of the disease. However, until now, experimental data in models of chronically infected chagasic mice linking the effects on myocardial $\beta$ adrenergic and muscarinic receptors to cardiopulmonary dysfunction is lacking. Thus, we studied C57BL/6 mice 8 months after intraperitoneal injection of 100 trypomastigote forms of the Colombian strain of T. cruzi. Uninfected mice, matched in age, were used as controls. Histopathological analyses (inflammation and fibrosis) and radio-ligand binding assays for estimation of muscarinic and adrenergic receptor density were performed in myocardium tissue samples. When compared to controls, infected mice had electrical conduction disturbances, diastolic dysfunction, lower $\mathrm{O}_{2}$ consumption and anaerobic threshold. In addition, hearts of chronic chagasic mice had intense inflammation and fibrosis, and decreased $\beta$ adrenergic and increased muscarinic receptor densities than normal controls. Our data suggest that chronic T. cruzi infection causes alterations in cardiac receptor density and fibrosis deposition which can be associated with cardiac conduction abnormalities, diastolic dysfunction and lower exercise capacity, associating for the first time all these functional and histopathological alterations in chagasic mice.
\end{abstract}

Key words: Chagas' disease, cardiopulmonary function, cardiac receptors, mouse model.

\section{INTRODUCTION}

Chagas' disease, caused by a haemoflagellate protozoan parasite Trypanosoma cruzi, is one of the most common determinants of congestive heart failure and sudden death in Latin America, where it represents a serious health problem, affecting millions of persons (WHO, 1995). Chagas' disease is a complex illness that can evolve in different consecutive phases. The first corresponds to an acute phase occurring after the parasite infection and characterized by intense parasitism and blood parasitaemia. After this, an asymptomatic or indeterminate period, marked by the absence of clinical symptoms is observed. Finally, months or decades after the primary infection, some of the infected individuals enter the chronic phase, which is characterized by chronic myocarditis and the so-called mega syndromes,

* Corresponding author: Instituto de Biofísica Carlos Chagas Filho, Universidade Federal do Rio de Janeiro, Cidade Universitária, Ilha do Fundão - 21941-900, Rio de Janeiro, Brazil. E-mail address: acarlos@biof.ufrj.br affecting the gastro-intestinal tract. Less than $10 \%$ of chronic patients present gastrointestinal abnormalities, such as pathological dilations of organs from the digestive tract (Dias, 1989; Dias and Coura, 1997). Approximately $30 \%$ of the infected individuals show heart involvement leading to heart failure. Furthermore, the chronic chagasic cardiomyopathy $(\mathrm{CChC})$ is characterized by intense myocarditis and multiple arrhythmias, such as ventricular premature beats, complete right bundle branch block, left anterior fascicular block and atrioventricular block (Koerbele, 1968; Rassi et al. 1992).

The mechanism responsible for the development of cardiomyopathy is still controversial and several hypotheses have been proposed. One hypothesis is based on an immune response directed against $T$. cruzi antigens at sites of parasite persistence, leading to a pathogenic inflammatory process (Tarleton, 2001; Higuchi et al. 1997). Another hypothesis is that $\mathrm{CChC}$ is the result of an autoimmune process triggered in some individuals by T. cruzi infection (Cunha-Neto et al. 1995 ; Engman and Leon, 2002). The autoimmunity hypothesis is 
supported by the lack of parasites at lesion sites in the chronic phase of the disease and the presence of autoantibodies in the sera from chagasic patients that recognize a number of cardiac-specific antigens, such as myosin, $\beta_{1}$ adrenergic and $\mathrm{M}_{2}$ muscarinic receptors (Borda et al. 1984; McCornick and Rowland, 1989; Sterin-borda et al. 1991; CunhaNeto, 1995; Farias et al. 1997; Goin et al. 1997). Another mechanism attributes $\mathrm{CChC}$ to vascular alterations, which lead to inflammatory and ischaemic changes (Tanowitz et al. 1996; Petkova et al. 2001). In addition, a neurogenic hypothesis has been proposed, in which autonomic denervation is associated with cardiac disturbances (Davila et al. 1989).

Much of the information about the pathogenesis of Chagas' disease comes from experimental models of chronic chagasic cardiomyopathy, especially using the mouse model. The murine model of $\mathrm{CChC}$ reproduces many of the structural, functional and immunological alterations observed in human CChC (Tanovitz et al. 1996; Petkova et al. 2001; Tarleton, 2001; Engman and Leon, 2002). Until now, however, no comprehensive study has been done analysing the functional, histopathological and receptor density alterations associated with the mouse model of $\mathrm{CChC}$. In this work we investigated the association between the cardiopulmonary function, heart histopathology and muscarinic and $\beta$ adrenergic receptor density adaptations in chronically infected mice.

\section{MATERIALS AND METHODS}

\section{Animals and infection}

Two-month-old C57BL/6 female mice raised and maintained in the animal facilities at the Gonçalo Moniz Research Center-FIOCRUZ, with rodent diet and water ad libitum were used in the experiments. They were infected by intraperitoneal injection of 100 trypomastigote forms of the Colombian strain of T. cruzi (Frederici et al. 1964). Trypomastigotes were obtained by in vitro infection of the LCC-MK2 cell line. Parasitaemia was evaluated at different times after infection by counting the number of trypomastigotes in peripheral blood samples (Brener, 1973). All infected animals were studied 8 months after the initial infection with the parasites, at 10 months of age. Uninfected female mice, matched in age, were used as controls. The current investigation conformed to the Guide for Care and Use of Laboratory Animals, published by the US National Institutes of Health.

\section{Electrocardiogram}

ECG records were performed using the Bio Amp device PowerLab System (PowerLab 2/20;
ADInstruments, Castle Hill, Australia), recording the bipolar lead I. All animals were anaesthetized by intraperitoneal injection of xilazine at $10 \mathrm{mg} / \mathrm{kg}$ body weight and ketamine at $100 \mathrm{mg} / \mathrm{kg}$ body weight. Electrocardiographic recordings were obtained after the induction of general anaesthesia. All data were transferred to a computer for further analysis using Chart 5 for Windows software (Power Lab; ADInstruments, Castle Hill, Australia). Wave durations (ms) were calculated automatically by the software after cursor placement. Measurements are average values determined from 14 consecutive ECG records obtained using bandpass filtering (1 to $100 \mathrm{~Hz}$ ). The sampling rate was $1 \mathrm{kHz}$. ECG analysis included the following measurements: heart rate; PR interval; $\mathrm{P}$ wave duration; QT interval; QTc; atrioventricular block; intraventricular block and other arrhythmias. The heart rate corresponded to $\mathrm{P}$ wave frequency calculated from the mean $\mathrm{P}$ wave interval duration when $\mathrm{AV}$ conduction was not $1: 1$, or it could be calculated directly by the software using a derivate-based QRS detection algorithm to calculate heart rate by detecting the peak of $\mathrm{R}$ waves automatically. As in rodent ECGs $\mathrm{T}$ waves are normally not separated from QRS complex, QT interval was measured instead of QRS complex duration (Bestetti and Oliveira, 1990). The QT interval was measured from the beginning of the QRS up to the end of the T wave. Definition of the end of the $T$ wave was the point where the signal returned to the isoelectric line (Wang et al. 2000). QTe was calculated dividing the QT interval by the square root of the RR interval. The values of all intervals and waves duration were expressed in milliseconds.

\section{Echocardiography}

Echocardiographic analyses were performed using a 2-dimensional echo Doppler cardiogram (Esaote, model CarisPlus, Firenze-Italy). The standard parasternal long and short axis views were obtained with a $10 \mathrm{MHz}$ transducer. All animals were anaesthetized by intraperitoneal injection of xilazine at $10 \mathrm{mg} / \mathrm{kg}$ and ketamine at $100 \mathrm{mg} / \mathrm{kg}$ body weight. The following parameters were acquired according to the American Society of Echocardiography: diameters of the left ventricle in diastole $(\mathrm{LVd})$ and systole (LVs), septal and posterior wall thickness, shortening fraction (SF), left ventricular ejection fraction and aortic valve area at M-mode and B-mode (AVA), isovolumetric relaxation time (IRT), the early (E) and late (A) peaks of diastolic transmitral flow velocities, E deceleration time (EDT), ejection time (ET), maximal aortic velocity (AoVmax) and flow velocity integral of aortic flow (FVI) using Doppler. The cardiac output (CO) was obtained from the product of FVI by AVA and heart rate. 


\section{Cardio-pulmonary exercise testing analyses}

All animals were weighed before the exam. A motordriven treadmill chamber (AccuScan Instruments, Model LC2/M, USA) was used to exercise the animals. Room air was pumped into the chamber at a flow rate (j) of $680 \mathrm{ml} / \mathrm{min}$. Outflow (same as $\mathrm{j}$ ) was set at $680 \mathrm{ml} / \mathrm{min}$ and directed to an oxygen and carbon dioxide analyser (Sable Systems FC-1B $\mathrm{O}_{2}$ and $\mathrm{CA}-2 \mathrm{~A} \mathrm{CO}_{2}$ Analyzers, USA), to measure the maximal consumption of oxygen $\left(\mathrm{VO}_{2} \max \right)$, the production of carbon dioxide $\left(\mathrm{VCO}_{2}\right)$, the respiration exchange ratio (RER) and the anaerobic threshold during exercise. Tests were performed at a 10 degree fixed inclination (ACCUPACER treadmill, ACCUSCAN Instruments, Inc., Columbus, Ohio, USA) and mean room temperature was maintained at $22{ }^{\circ} \mathrm{C}$. Mice were placed in the treadmill chamber for an adaptation period of $5 \mathrm{~min}$ before running for $5 \mathrm{~min}$ at 4 different velocities $(0 \cdot 1,0 \cdot 2,0 \cdot 3$ and $0.4 \mathrm{~m} / \mathrm{s}$ ) and maintained in the last velocity until exhaustion. Stainless steel grids at the end of the treadmill provided an electrical stimulus to keep the mice running. The criterion for reaching $\mathrm{VO}_{2} \max$ was its levelling off despite increasing running velocity or when animals stayed in the steel grids for more than $10 \mathrm{sec}$. Another criterion for reaching $\mathrm{VO}_{2}$ max was a RER above $1 \cdot 0 . \mathrm{VO}_{2}$ consumption and $\mathrm{CO}_{2}$ production were obtained by the following formulae:

$$
\begin{aligned}
\mathrm{VO}_{2} \max = & \left(\% \mathrm{O}_{2} \max -\% \mathrm{O}_{2} \text { adaptation }\right) \\
& \times 680 \mathrm{ml} / \mathrm{min} / \text { weight }(\mathrm{kg})
\end{aligned}
$$

$$
\begin{aligned}
\mathrm{VCO}_{2}= & \left(\% \mathrm{CO}_{2} \text { at end }-\% \mathrm{CO}_{2} \text { adaptation }\right) \\
& \times 680 \mathrm{ml} / \mathrm{min} / \text { weight }(\mathrm{kg})
\end{aligned}
$$

The anaerobic threshold was determined at the point where the curves for $\mathrm{VO}_{2}$ levelled off or stabilized and the $\mathrm{CO}_{2}$ continued to increase. The result was expressed as $\mathrm{ml} / \mathrm{kg} / \mathrm{min}$ of $\mathrm{VO}_{2}$ consumption.

\section{Histopathological analysis}

Hearts from chronic chagasic and normal mice were removed and sectioned transversally in 3 segments. One fresh segment was processed for the radioligand binding assay. The other segments were fixed in buffered $10 \%$ formalin. Sections of paraffinembedded tissue were stained with standard haematoxylin/eosin and Sirius red staining for evaluation of inflammation and fibrosis, respectively, by optical microscopy. Images were digitalized using a colour digital video camera (CoolSnap, Montreal, Canada) adapted to a BX41 microscope (Olympus, Japan). The images were analysed using the Image Pro Program version 5.0 (Media Cybernetics, San Diego, CA), to integrate the number of inflammatory cells counted by unit area or the whole fibrotic area. Ten fields were counted per heart from every mouse of each group.

\section{Preparation of homogenates for the radio-ligand binding experiments}

Heart fragments were minced and suspended in buffer A $(25 \mathrm{mmol} / 1 \mathrm{HEPES}, 1 \mathrm{mmol} / \mathrm{l}$ EDTA, $0 \cdot 1 \mathrm{mmol} / \mathrm{l} \mathrm{PMSF}$, and $5 \mathrm{mmol} / \mathrm{l} \mathrm{MgCl}_{2}, \mathrm{pH} 7 \cdot 5$ ) and then homogenized with three $15 \mathrm{sec}$ strokes with a Tissumizer (Tekmar Company, Cincinnati, $\mathrm{OH}$, USA) and $60 \mathrm{sec}$ resting intervals. The suspensions were filtered through cheesecloth and centrifuged at $4{ }^{\circ} \mathrm{C}$ for $15 \mathrm{~min}$ at $48000 \mathrm{~g}$. The resulting pellets were resuspended in buffer $\mathrm{B}$ (similar to buffer $\mathrm{A}$, except for $2 \mathrm{mmol} / 1 \mathrm{MgCl}_{2}$ ) with the aid of a Teflonglass homogenizer. Next, the suspensions were centrifuged again for $30 \mathrm{~min}$ at $48000 \mathrm{~g}$. Finally, the pellets were resuspended in buffer $\mathrm{B}$ and stored at $-70{ }^{\circ} \mathrm{C}$ as described previously (Giménez et al. 2005).

Radio-ligand binding assay. $\beta$-adrenergic receptor density $\left(\mathrm{B}_{\mathrm{MAX}}\right)$ was determined by $\left[{ }^{3} \mathrm{H}\right]$ dihydroalprenolol hydrochloride $\left(\left[{ }^{3} \mathrm{H}\right]-\mathrm{DHA}, 120 \mathrm{CI} / \mathrm{mmol}\right.$, New England Nuclear, Boston, MA, USA) saturation binding assays. The homogenates $(150 \mu \mathrm{g}$ of total protein) were incubated in buffer $\mathrm{C}(25 \mathrm{mmol} / 1$ Tris- $\mathrm{HCl}, 1 \mathrm{mmol} / \mathrm{l}$ EDTA and $5 \mathrm{mmol} / \mathrm{l} \mathrm{MgCl}_{2}$, $\mathrm{pH} 7 \cdot 5)$ with increasing concentrations of $\left[{ }^{3} \mathrm{H}\right]-\mathrm{DHA}$ $(5-80 \mathrm{nmol} / \mathrm{l})$ at $25^{\circ} \mathrm{C}$ for $1 \mathrm{~h}$ in a final volume of $400 \mu \mathrm{l}$. The reaction was stopped by rapid vacuum filtration using a cell harvester (Brandel, Gaithersburg, MD, USA) through GF/B glass fibre filters pre-soaked in $0 \cdot 3 \%$ polyethylenimine followed by 3 fast washes with ice-cold $10 \mathrm{mmol} / 1$ phosphate buffer, pH 7·4. Trapped radioactivity was determined by liquid scintillation counting (efficiency of $36 \%$, Packard Instruments CO., Meriden, CT, USA). Non-specific binding was defined as the bound radioactivity in the presence of unlabelled propranolol $(10 \mu \mathrm{mmol} / \mathrm{l})$. Specific $\left[{ }^{3} \mathrm{H}\right]$-DHA binding activity was estimated by subtracting the nonspecific binding from the total binding.

Muscarinic receptor density was determined by L-[N-methyl- $\left.{ }^{3} \mathrm{H}\right]$ scopolamine methyl chloride $\left(\left[{ }^{3} \mathrm{H}\right]-\mathrm{NMS}, 84 \mathrm{Ci} / \mathrm{mmol}\right.$, Amersham Biosciences, Piscataway, NJ, USA) saturation binding assays. Accordingly, homogenates $(150 \mu \mathrm{g})$ were incubated in buffer $\mathrm{B}$ with increasing concentrations of $\left[{ }^{3} \mathrm{H}\right]$ NMS (10-1200 pmol/l) at $37^{\circ} \mathrm{C}$ for $2 \mathrm{~h}$ in a final volume of $2 \mathrm{ml}$. Non-specific binding was defined by unlabelled atropine $(2 \mu \mathrm{mol} / \mathrm{l})$ at $37^{\circ} \mathrm{C}$ for $2 \mathrm{~h}$. Subsequent procedures were performed as previously described for the $\beta$-adrenergic receptor. Estimates of maximal bound $\left(\mathrm{B}_{\max }\right)$ and the equilibrium dissociation constant $\left(\mathrm{K}_{\mathrm{D}}\right)$ were obtained from least square curve fitting analysis according to 
Table 1. Echocardiography analysis in Trypanosoma cruzi-infected mice

$(\mathrm{LA}=$ left atrium diameter $; \mathrm{LVd}=$ left ventricular diameter in diastole $; \mathrm{LVs}=$ left ventricular diameter in systole $; \mathrm{FS}=$ percentual of fractional shortening; $\mathrm{EF}=$ left ventricular ejection fraction at M-mode; $\mathrm{EDT}=$ peak early diastolic transmitral flow velocity; $\mathrm{E} / \mathrm{A}=$ ratio between peak early $(\mathrm{E})$ and late $(\mathrm{A})$ diastolic transmitral flow velocities; IRT $=$ isovolumetric relaxation time; $\mathrm{ET}=$ ejection time; $\mathrm{AoV}$ $\max =$ maximal aortic velocity $; \mathrm{CO}=$ cardiac output. Values represent the mean \pm S.E.M.)

\begin{tabular}{lccc}
\hline \hline Parameters & $\begin{array}{l}\text { Control group } \\
n=5\end{array}$ & $\begin{array}{l}\text { Infected group } \\
n=6\end{array}$ & $P$ \\
\hline LA (cm) & $0 \cdot 17 \pm 0 \cdot 02$ & $0 \cdot 18 \pm 0 \cdot 03$ & $0 \cdot 4741$ \\
LVd (cm) & $0 \cdot 27 \pm 0 \cdot 04$ & $0 \cdot 29 \pm 0 \cdot 05$ & $0 \cdot 1866$ \\
LVs (cm) & $0 \cdot 11 \pm 0 \cdot 01$ & $0 \cdot 15 \pm 0 \cdot 05$ & $0 \cdot 0570$ \\
Septal wall (cm) & $0 \cdot 07 \pm 0 \cdot 01$ & $0 \cdot 08 \pm 0 \cdot 00$ & $0 \cdot 0477$ \\
Posterior wall (cm) & $0 \cdot 07 \pm 0 \cdot 01$ & $0 \cdot 08 \pm 0 \cdot 01$ & $0 \cdot 1540$ \\
FS $(\%)$ & $60 \pm 3$ & $53 \pm 13$ & $0 \cdot 1584$ \\
EF $(\%)$ & $93 \pm 2$ & $86 \pm 12$ & $0 \cdot 1157$ \\
EDT (ms) & $29 \pm 10$ & $55 \pm 11$ & $0 \cdot 0044$ \\
E/A & $0 \cdot 97 \pm 0 \cdot 65$ & $2 \cdot 18 \pm 0 \cdot 42$ & $0 \cdot 0305$ \\
IRT (ms) & $29 \pm 14$ & $46 \pm 22$ & $0 \cdot 1143$ \\
ET (ms) & $75 \pm 11$ & $106 \pm 16$ & $0 \cdot 0056$ \\
AoVmax (m/s) & $0 \cdot 50 \pm 0 \cdot 13$ & $0 \cdot 30 \pm 0 \cdot 17$ & $0 \cdot 0414$ \\
CO (L/min) & $0 \cdot 01 \pm 0 \cdot 03$ & $0 \cdot 02 \pm 0 \cdot 01$ & $0 \cdot 2340$ \\
\hline \hline
\end{tabular}

the rectangular hyperbolic model using the GraphPad Prism 4.03 software (San Diego, CA, USA).

\section{Statistical analyses}

All continuous variables were presented as mean \pm standard error, except for receptor density data. Histological data and cardiopulmonary parameters were analysed using Student's $t$-test and Mann Whitney test with Prism Software version 3.0 (GraphPad Software, San Diego, CA, USA). For analysis of receptor density we employed the nonlinear regression analysis of radio-ligand saturation experiments. Differences were considered significant if $P$ was equal to or less than $0 \cdot 05$.

\section{RESULTS}

\section{Altered echocardiographic parameters in chronic chagasic mice}

In order to evaluate the echocardiographic disturbances induced by T. cruzi infection in the murine model, non-infected and chronic chagasic C57BL/6 mice ( 8 months after infection) were subjected to echocardiography under anaesthesia. Table 1 summarizes the parameters obtained from both groups. Mice infected with T. cruzi had a thicker septal wall, a higher EDT, a higher E/A, a higher ET and a lower AoV max when compared to uninfected controls.

T. cruzi infection induces lower resistance to exercise in mice. To investigate whether T. cruzi infection compromises the exercising capacity of infected mice, treadmill test and respiratory gas analyses were performed in age-matched infected and non-infected mice. Chronic chagasic mice endured less exercise duration and had lower $\mathrm{VO}_{2}$ max, higher RER, and lower anaerobic threshold when compared to controls (Table 2).

\section{Chronic chagasic mice develop functional and structural abnormalities}

To demonstrate the involvement of T. cruzi infection in the development of cardiac electric abnormalities we recorded the electric extracellular activity from chronic chagasic and normal mice by electrocardiogram. All infected mice had arrhythmias such as intraventricular conduction disturbances, atrioventricular block and atrioventricular dissociation (Fig. 1A, Table 3). Electrocardiographic analyses in control $\mathrm{C} 57 \mathrm{BL} / 6$ mice had no abnormalities (Fig. 1B, Table 3).

Histopathological analysis of heart sections demonstrated a 2 -fold increase in the number of inflammatory cells in infected mice (Fig. 2A) in relation to normal mice. With regard to heart fibrosis, infected mice had significantly more fibrotic areas when compared to control mice (Fig. 2B; * $P<0 \cdot 05$, Student's $t$-test and Mann-Whitney test).

\section{Muscarinic and $\beta$ receptor densities are altered in T. cruzi-infected mice}

To determine the density of the muscarinic and $\beta$ adrenergic cardiac receptors, we performed radioligand saturation experiments. As shown in Table 4, maximal $\left[{ }^{3} \mathrm{H}\right]$ NMS binding to cardiac $\mathrm{mAChR}$ is 
Table 2. Results of cardiopulmonary exercise testing

$\left(\mathrm{VO}_{2} \max =\right.$ maximum consumption of oxygen; $\mathrm{VCO}_{2}=$ carbon dioxide production; $\mathrm{RER}=$ respiratory equilibration rate $\left(=\mathrm{VO}_{2} / \mathrm{VCO}_{2}\right)$. Values represent the mean \pm S.E.M.)

\begin{tabular}{lccc}
\hline \hline Parameters & $\begin{array}{l}\text { Control group } \\
n=5\end{array}$ & $\begin{array}{l}\text { Infected group } \\
n=6\end{array}$ & $P$ \\
\hline Exercise duration (min) & $13 \pm 2$ & $5 \pm 2$ & $0 \cdot 0001$ \\
$\mathrm{VO}_{2} \mathrm{max}(\mathrm{ml} / \mathrm{kg} / \mathrm{min})$ & $56 \pm 18$ & $27 \pm 10$ & $0 \cdot 0041$ \\
$\mathrm{VCO}_{2}(\mathrm{ml} / \mathrm{kg} / \mathrm{min})$ & $68 \pm 14$ & $53 \pm 15$ & $0 \cdot 0600$ \\
$\mathrm{RER}$ & $1 \cdot 28 \pm 0 \cdot 30$ & $2 \cdot 06 \pm 0 \cdot 46$ & $0 \cdot 0088$ \\
$\mathrm{VO}$ & $42 \pm 12$ & $20 \pm 6$ & $0 \cdot 0068$ \\
$(\mathrm{ml} / \mathrm{kg} / \mathrm{min})$ & & & \\
\hline \hline
\end{tabular}
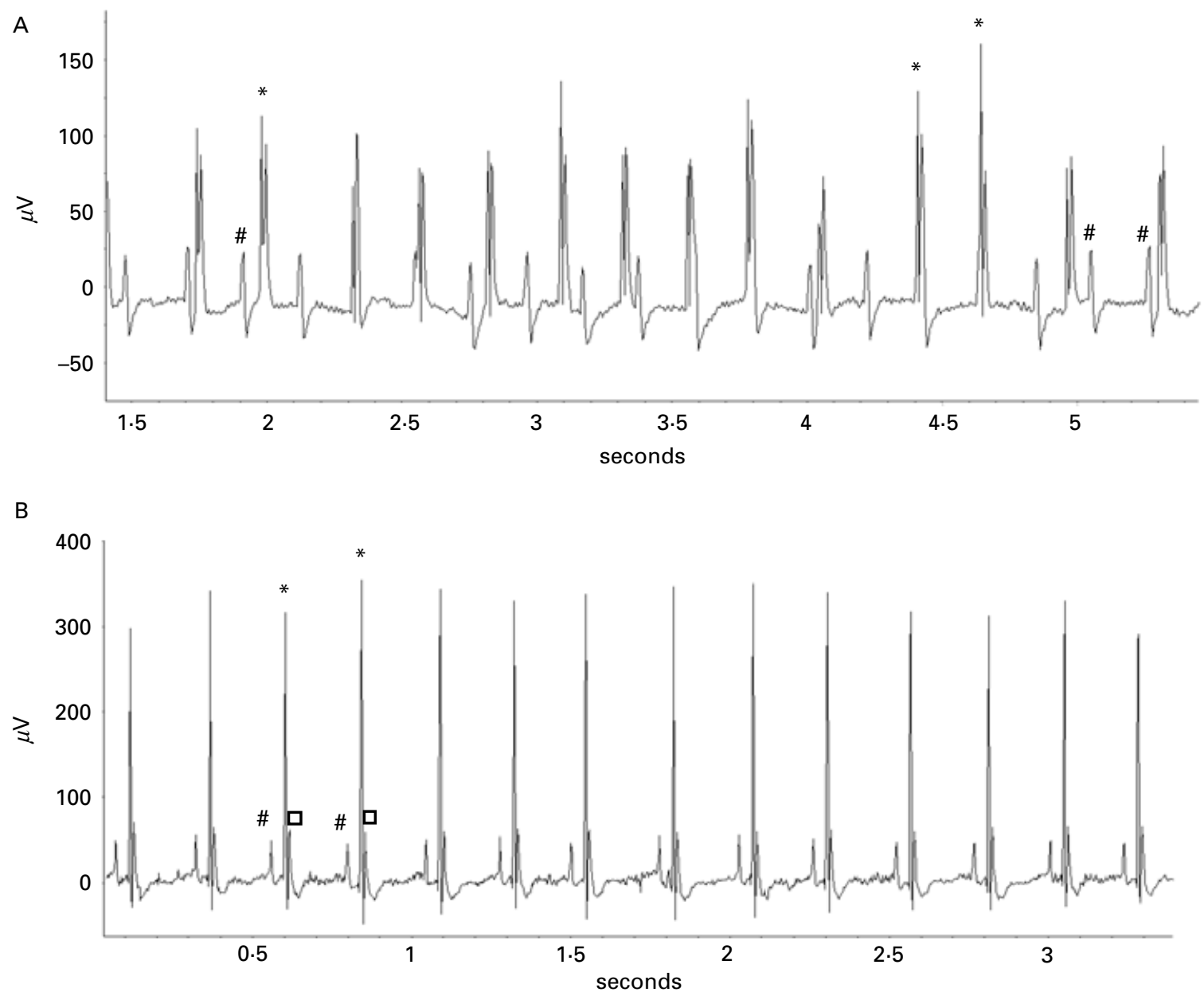

Fig. 1. ECG recordings from C57B1/6 mice. (A) ECG of a Trypanosoma cruzi-infected mouse recorded 8 months after infection showing total AV conduction block and intraventricular conduction disturbances. $\mathrm{P}$ wave frequency was $350 \mathrm{bpm}$. (B) ECG recorded in a control C57Bl/6 mouse with regular sinus rhythm and beat rate of $240 \mathrm{bpm}$. \#, P wave; *, QRS complex; $\square$, $\mathrm{T}$ wave.

increased in the $T$. cruzi-infected group as compared to controls $(226.3$ and $123.4 \mathrm{fmol} / \mathrm{mg}$ of protein, respectively). The affinity of $\left[{ }^{3} \mathrm{H}\right]$ NMS to the receptor in infected mice, although showing a tendency, was not significantly different from the control group $(197.0$ and $91.7 \mathrm{pmol} / 1$, respectively). In contrast to what was observed with the muscarinic receptor density, maximal $\left[{ }^{3} \mathrm{H}\right]$-DHA binding for the $T$. cruzi-infected group was decreased in comparison to the control group $(22 \cdot 7 \mathrm{fmol} / \mathrm{l}$ and $31 \cdot 5 \mathrm{fmol} / \mathrm{mg}$ of protein, respectively). As with the cardiac mAChRs, no differences were observed for the equilibrium dissociation constant $\left(\mathrm{K}_{\mathrm{D}}\right)$ (Table 4$)$.

\section{DISCUSSION}

Chronic chagasic cardiomyopathy in mice is a wellstudied model to investigate the physiopathology of 
Table 3. Eletrocardiographic parameters measured in the experimental groups

(Values represent the mean \pm S.E.M. of the studied mice. In the infected group the heart rate was calculated by $\mathrm{P}$ wave interval when AV conduction was not $1: 1$. and PR intervals were only measured in animals were AV conduction was $1: 1$ ( $n=4$ for the infected group). AVD, atrioventricular dissociation; IVCD, intraventricular conduction disturbance; AVB, atrium-ventricular block; ASI, acute subendocardial ischemia; SB, Sinusal blockage. ${ }^{*} P<0 \cdot 05$ compared to Trypanosoma cruzi-infected mice, Student's $t$-test. Some animals developed more than one type of cardiac conduction disturbances.)

\begin{tabular}{|c|c|c|c|c|c|c|}
\hline $\begin{array}{l}\text { Experimental } \\
\text { group }(n)\end{array}$ & $\begin{array}{l}\text { Heart rate } \\
(\mathrm{bpm})\end{array}$ & $\begin{array}{l}\text { PR interval } \\
(\mathrm{ms})\end{array}$ & $\begin{array}{l}\text { RR interval } \\
(\mathrm{ms})\end{array}$ & $\begin{array}{l}\text { QT interval } \\
(\mathrm{ms})\end{array}$ & $\mathrm{QT}_{\mathrm{c}}$ & $\begin{array}{l}\text { Cardiac conduction } \\
\text { disturbances }\end{array}$ \\
\hline Infected $(n=6)$ & $315 \pm 69 \cdot 2 *$ & $81 \pm 8 \cdot 0 *$ & $213 \pm 68 \cdot 6^{*}$ & $41 \pm 5 \cdot 8^{*}$ & $2 \cdot 9 \pm 0 \cdot 73^{*}$ & $\begin{array}{l}\operatorname{AVD}(n=2) \\
\operatorname{IVCD}(n=4) \\
\operatorname{AVB}(n=4) \\
\operatorname{ASI}(n=4) \\
\operatorname{SB}(n=1)\end{array}$ \\
\hline Control $(n=5)$ & $223 \pm 40 \cdot 2$ & $49 \pm 4 \cdot 4$ & $277 \pm 55 \cdot 0$ & $31 \pm 2 \cdot 3$ & $1 \cdot 8 \pm 0 \cdot 22$ & - \\
\hline
\end{tabular}

Table 4. $\left[{ }^{3} \mathrm{H}\right]$-NMS and $\left[{ }^{3} \mathrm{H}\right]$-DHA saturation binding parameters from control and Trypanosoma cruzi-infected mice heart homogenates

\begin{tabular}{|c|c|c|c|c|c|c|}
\hline \multirow[b]{2}{*}{$\begin{array}{l}\text { Ligand/Binding } \\
\text { Parameter }\end{array}$} & \multicolumn{3}{|c|}{$\begin{array}{l}\text { Muscarinic receptor } \\
\text { antagonist }\left(\left[{ }^{3} \mathrm{H}\right]-\mathrm{NMS}\right)\end{array}$} & \multicolumn{3}{|c|}{$\begin{array}{l}\beta \text { - Adrenergic receptor } \\
\text { antagonist }\left(\left[{ }^{3} \mathrm{H}\right] \text {-DHA }\right)\end{array}$} \\
\hline & $\begin{array}{l}\text { Control } \\
\text { group }\end{array}$ & $\begin{array}{l}\text { T. cruzi- } \\
\text { infected } \\
\text { group }\end{array}$ & $P^{*}$ & $\begin{array}{l}\text { Control } \\
\text { group }\end{array}$ & $\begin{array}{l}\text { T. cruzi- } \\
\text { infected } \\
\text { group }\end{array}$ & $P^{*}$ \\
\hline $\begin{array}{l}\mathrm{B}_{\text {MAX }}(\mathrm{fmol} / \mathrm{mg} \text { of } \\
\text { total protein) }\end{array}$ & $123 \cdot 4 \pm 8 \cdot 8$ & $226 \cdot 3 \pm 15 \cdot 4$ & $0 \cdot 004$ & $585 \cdot 9 \pm 43 \cdot 5$ & $372 \cdot 5 \pm 33 \cdot 4$ & $0 \cdot 018$ \\
\hline $\mathrm{K}_{\mathrm{D}} \S$ & $91 \cdot 7 \pm 24 \cdot 7$ & $197 \cdot 0 \pm 40 \cdot 6$ & $0 \cdot 091$ & $22 \cdot 7 \pm 8 \cdot 5$ & $31 \cdot 5 \pm 10 \cdot 6$ & $0 \cdot 811$ \\
\hline
\end{tabular}

* Statistical difference between the means was determined by the unpaired Student's $t$-test (two tails). $P<0 \cdot 05$ was considered significant.

$\S \mathrm{K}_{\mathrm{D}}$ values for $\left[{ }^{3} \mathrm{H}\right]$-NMS are given in $\mathrm{pmol} / \mathrm{l}$ and for $\left[{ }^{3} \mathrm{H}\right]$-DHA in $\mathrm{nmol} / \mathrm{l}$.
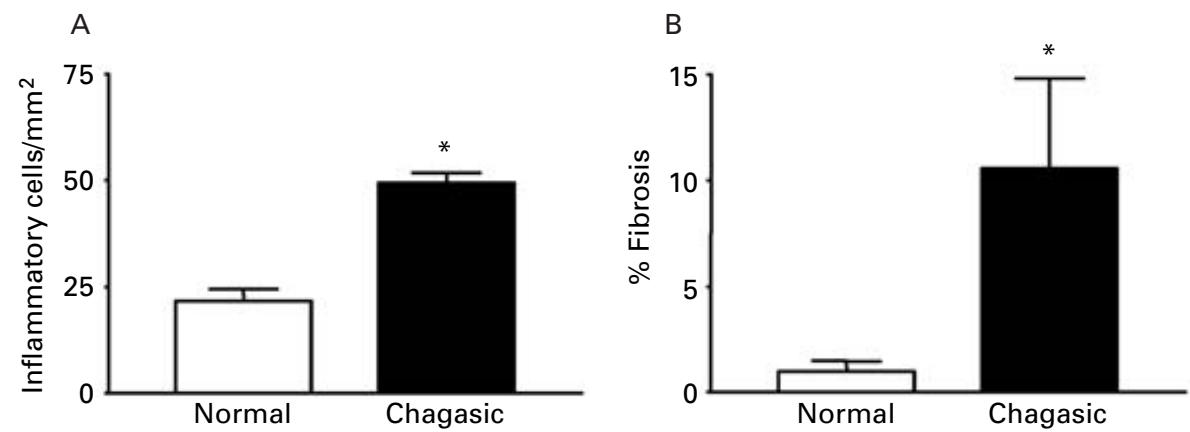

Fig. 2. Morphometrical analyses of heart sections from normal and infected mice. Quantification of inflammatory cells (A) and of fibrosis (B) in heart sections of C57Bl/6 control mice and Trypanosoma cruzi-infected C57Bl/6 mice. Values represent the mean \pm S.D. of 6 mice/group (A) and 8 mice/group (B). ${ }^{*} P<0 \cdot 05$, compared to normal group, Student's $t$-test and Mann-Whitney test.

the disease because it resembles the human illness characterized by inflammatory mononuclear cell infiltration, electro- and echocardiographic abnormalities and reactive cardiac antibodies (Gorelik et al. 1992; Mirkin et al. 1994; Goin et al. 1999; Garcia et al. 2005). In our study we simultaneously evaluated, for the first time, mechanical, electrical, biochemical (increase in $\mathrm{M}_{2}$ cardiac receptor density) and structural cardiac abnormalities, and myocarditis in $T$. cruzi-infected mice.
Doppler echocardiography is an important noninvasive tool for the assessment of diastolic function. Doppler inflow velocity-derived variables remain the cornerstone of diastolic function evaluation. The 4 useful variables obtained from mitral flow interrogation are peak early diastolic transmitral flow velocity (E), peak late diastolic transmitral flow velocity (A), early filling deceleration time (DT) and A-wave duration. We used the analysis of the first 3 variables. In our study, mice infected with $T$. cruzi had a ratio 
E/A >1, a prolonged EDT and normal FS and left ventricular EF. These findings are compatible with severe diastolic dysfunction or restrictive pattern, in which a severe decrease in compliance leads to further elevation of left atrial pressure and results in very high $\mathrm{E}$ wave, low $\mathrm{A}$ wave and progressive shortening of EDT. In chagasic patients, diastolic heart failure is associated with a marked increase in morbidity and all-cause mortality independent of the presence of systolic failure.

Impairment in diastolic filling may be related to both abnormalities of active relaxation of the myocardium and passive elastic properties as a result of hypertrophy, myocardial ischaemia, decreased adrenergic tone, or increased myocardial connective tissue. Accordingly, the T. cruzi-infected group had decreased adrenergic receptor density and an increase in inflammation and fibrosis, factors that may explain the diastolic dysfunction observed in the present study. We did not find differences in isovolumic relaxation time (IVRT) between the groups. It is possible that the inability of the left ventricle to fill in early diastole and a progressive elevation of left atrial pressure results in an early opening of the mitral valve and return of the IVRT to values observed under normal conditions.

During cardiopulmonary exercise testing our mice showed reduced exercise duration, lower $\mathrm{VO}_{2 \max }$ and anaerobic threshold. Depletion of $\beta$ receptors could be one of the explanations for the low functional capacity during cardiopulmonary exercise testing in our infected mice. Other possibilities are: impairment in relaxation increases myocardial wall tension in diastole, and loss of cardiac elastic properties causes a reduction in compliance, both of which may lead to an increase in pulmonary venous pressure. Patrianakos et al. (2004) showed that patients with restrictive pattern had not only lower cardiopulmonary exercise test but also higher $\mathrm{N}$-terminal pro-atrial (ANP) and $\mathrm{N}$-terminal pro-brain natriuretic peptide (BNP) levels [27]. They also found a significant correlation between BNP levels and maximal oxygen consumption. A reasonable explanation is that patients with elevated left ventricular diastolic pressures at rest are prone to marked elevation of capillary wedge pressure during exercise and this may be the reason for the observed correlation between natriuretic peptides and exercise capacity.

ECG data demonstrate an increased $\mathrm{P}$ wave frequency associated with augmented PR and QT intervals in infected mice. This suggests that the increased heart rate is not the result of higher adrenergic activity, as indicated by the lower beta-adrenergic receptor density detected in our experiments. If this was the case one should expect increased $\mathrm{P}$ wave rate associated with decreased PR and QT intervals. Therefore we speculate that the increase in heart rate can result from local mechanisms related to a higher degree of inflammation observed in hearts from infected mice. In this regard the mouse model seems to differ from the human case, where bradychardia is the most common finding.

Sera from chagasic patients contain antibodies that can react 'in vitro' with plasma membrane of living heart cells inducing functional changes and modifying their $\beta$ adrenergic and cholinergic receptor activities (Masuda et al. 1998; Hernández et al. 2003). In the present study radio-ligand binding assays showed an increased density of muscarinic receptors only in the infected group. Many reports demonstrated a relevant role for $\mathrm{M}_{2}$ receptors in the development of cardiac conduction abnormalities (Masuda et al. 1998; Hernández et al. 2003), thus suggesting that the increased expression of $\mathrm{M}_{2}$ receptor may explain the various arrhythmias detected in the infected group.

More recently, Giménez et al. (2005) created murine models of autoimmune cardiomyopathy by gene gun DNA dermal bombardment using plasmids encoding the entire sequence of the $\mathrm{M}_{2}$ muscarinic acetylcholine and the $\beta_{1}$ adrenergic receptors. In this study, cardiac contractile impairment was most noticeable in the $\beta_{1}$ adrenergic receptor-immunized animals. Interestingly, muscarinic receptor density in hearts of both $\mathrm{M}_{2} \mathrm{AChR}$ and $\beta_{1}$ adrenergic receptor-immunized mice was significantly upregulated. On the other hand, $\beta_{1}$ adrenergic receptor density was similarly decreased in both experimental groups by a 2 -fold factor. In line with these previous studies, we observed an increase in muscarinic receptor density and a decrease in $\beta_{1}$ adrenergic receptor density in the murine model of Chagas' disease. Alternatively, the up- and down-regulation of muscarinic and adrenergic receptors, respectively, may be due to cardiac autonomic dysfunctions known to occur in chagasic cardiomyopathy.

In conclusion, the present study analyses a series of functional, biochemical and histopathological parameters in mice with chronic chagasic cardiomyopathy showing the typical inflammation and fibrosis, but also an up-regulation of muscarinic $\mathrm{M}_{2}$ receptors and a down-regulation in $\beta_{1}$ adrenergic receptors, all of which are compatible with the conduction disturbances, diastolic dysfunction and lower exercise capacity observed in these animals.

This work was supported by grants from the Brazilian Ministry of Science and Technology (Brazilian National Research Council- $\mathrm{CNPq}$ and Millenium Institute of Tissue Bioengeneering), FAPESB, FAPERJ and NIH (no. HLO73732-01).

REFERENCES

Bestetti, R. B. and Oliveira, J. S. (1990). The surface electrocardiogram: a simple and reliable method for detecting overt and latent heart disease in rats. 
Brazilian Fournal of Medical and Biological Research 2, 1213-1222.

Borda, E. P., Cossio, P., Vega, M. V., Arana, R. and Sterin-Borda, L. (1984). A circulating IgG in Chagas disease which binds to $\beta$-adrenoreceptors of myocardium and modulates their activity. Clinical and Experimental Immunology 57, 679-686.

Brener, Z. (1973). Biology of Trypanosoma cruzi. Annual Review of Microbiology 27, 347-382.

Cunha-Neto, E., Duranti, M., Gruber, A., Zingales, B., De Messias I., Stolf, N., Bellotti, G., Patarroyo, M. E., Pilleggi, F. and Kali1, J. (1995). Autoimmunity in Chagas disease cardiopathy : biological relevance of a cardiac myosin-specific epitope cross-reactive to an immunodominant Trypanosoma cruzi antigen. Proceedings of the National Academy of Sciences, USA 92, 3541-3545.

Davila, D. F., Rossell, R. O. and Donis, J. H. (1989). Cardiac parasympathetic abnormalities: cause or consequence of Chagas heart disease. Parasitology Today 5, 327-329.

Dias, J. C. P. (1989). The indeterminate form of human chronic Chagas' disease a clinical epidemiological review. Revista da Sociedade Brasileira de Medicina Tropical 22, 147-156.

Dias, J. C. P. and Coura, J. (1997). Clínica e Terapêutica da Doença de Chagas : uma Abordagem Prática Para o Clínico Geral. FIOCRUZ, Rio de Faneiro.

Engman, D. M. and Leon, J. S. (2002). Pathogenesis of Chagas' heart disease: role of autoimmunity. Acta Tropica 81, 123-132.

Farias, O. S., Pedrosa, R. C., Nascimento, J. H. M., Campos de Carvalho, A. C. and Masuda, M. O. (1997). Sera from chronic chagasic patients with complex cardiac arrhythmias depress electrogenesis and conduction in isolated rabbit hearts. Circulation 96, 2031-2037.

Frederici, E. C., Abelmann, W. N. and Neva, F. A. (1964). Chronic and progressive myocarditis in C3H mice infected with Trypanosoma cruzi. American Fournal of Tropical Medicine and Hygiene 13, 272-280.

Garcia, S., Ramos, C. O., Senra, J. F., Vilas-Boas, F., Rodrigues, M. M., Campos-de-Carvalho, A. C., Ribeiro-Dos-Santos, R. and Soares, M. B. (2005). Treatment with benznidazole during the chronic phase of experimental Chagas' disease decreases cardiac alterations. Antimicrobial Agents and Chemotherapy 49, 1521-1528.

Giménez, L. E., Hernández, C. C., Mattos, E. C., Brandão, I. T., Olivieri, B., Campelo, R. P., Araújo-Jorge, T., Silva, C. L., Campos de Carvalho, A. C. and Kurtenbach, E. (2005). DNA immunizations with M2 muscarinic and $\beta 1$ adrenergic receptor coding plasmids impair cardiac function in mice. Fournal of Molecular and Cellular Cardiology 38, 703-714.

Goin, J. C., Borda, E. S., Auger, S., Storino, R. and Sterin-Borda, L. (1999). Cardiac M(2) muscarinic cholinoceptor activation by human chagasic autoantibodies: association with bradycardia. Heart $\mathbf{8 2}$, 273-278.

Goin, J. C., Leiros, C. P., Borda, E. and Sterin-Borda, L. (1997). Interaction of human chagasic IgG with the second extracellular loop of the human heart muscarinic acetylcholine receptor: functional and pathological implications. FASEB Fournal 11, 77-83.

Gorelik, G., Borda, E., Bacman, S., Cremaschi, G. and Sterin-Borda, L. (1992). Chagasic IgG stimulates phosphoinositide hydrolysis via neurotransmitter receptor activation: role of calcium. Fournal of Lipid Mediators 5, 249-259.

Hernández, C. C. Q., Barcellos, L. C., Giménez, L. E. D., Cabarcas, R. A. B., Garcia, S., Pedrosa, R. C., Nascimento, J. H. M., Kurtenbach, E., Masuda, M. O. and Carvalho, A. C. C. (2003). Human chagasic IgGs bind to cardiac muscarinic receptors and impair L-type $\mathrm{Ca}^{2+}$ currents, Cardiovascular Research 58, 55-65.

Higuchi, M. D., Ries, M. M., Aiello, V. D., Benvenutti, L. D., Gutierrez, P. S., Bellotti, G. and Pileggi, F. (1997). Association of an increase in CD8+ T cells with the presence of Trypanosoma cruzi antigens in chronic, human, chagasic myocarditis. American Fournal of Tropical Medicine and Hygiene 56, 485-489.

Köerbele, F. (1968). Chagas' disease and Chagas' syndromes: the pathology of American Trypanosomiasis, Advances in Parasitology 6, 63-116.

Masuda, M. O., Levin, M., de Oliveira, S. F., Costa, P. C. S., Bergami, P. L., Almeida, N. A. S., Pedrosa, R. C., Ferrari, I., Hoebeke, J. and Carvalho, A. C. C. (1998). Functionally active cardiac antibodies in chronic Chagas disease are specifically blocked by Trypanosoma cruzi antigens. FASEB Fournal 12, 1551-1558.

McCornick, T. S. and Rowland, E. C. (1989). Trypanosoma cruzi: croos-reative anti-heart autoantibodies produced during infection in mice. Experimental Parasitology 69, 393-401.

Mirkin, G. A., Jones, M., Sanz, O. P., Rey, R., Sica, R. E. and Gonzalez Cappa, S. M. (1994).

Experimental Chagas' disease: electrophysiology and cell composition of the neuromyopathic inflammatory lesions in mice infected with a myotropic and a pantropic strain of Trypanosoma cruzi. Clinical Immunology and Immunopathology 73, 69-79.

Patrianakos, A. P., Parthenakis, F. L., Papadimitriou, E. A., Diakakis, G. F., Tzerakis, P. G., Nikitovic, D. and Vardas, P. E. (2004). Restrictive filling pattern is associated with increased humoral activation and impaired exercise capacity in dilated cardiomyopathy. European Heart Fournal 6, 735-743.

Petkova, S. B., Huang, H., Factor, S. M., Pestell, R. G., Bouzahzah, B., Jelicks, L. A., Weiss, L. M., Douglas, S. A., Wittner, M. and Tanowitz, H. B. (2001). The role of endothelin in the pathogenesis of Chagas' disease. International Fournal for Parasitology 31, 499-511.

Rassi, A. and Luquetti, A. Q. (1992). Chagas disease (American trypanosomiasis): its impact on transfusion and clinical medicine. In Therapy of Chagas Disease (ed. Wendel, S., Brener, Z., Camargo, M. G. and Rassi, A.), pp. 237-247. ISBT, Sao Paulo.

Sterin-Borda, L., Gorelik, G. and Borda, E. S (1991). Chagasic IgG binding with cardiac muscarinic cholinergic receptors modifies cholinergic-mediated cellular transmembrane signals. Clinical Immunology and Immunopathology 61, 387-397. 
Tanowitz, H. B., Kaul, D. K., Chen, B., Morris, S. A., Factor, S. M., Weiss, L. M. and Wittner, M. (1996). Compromised microcirculation in acute murine Trypanosoma cruzi infection. Fournal of Parasitology 82, 124-130.

Tarleton, R. L. (2001). Parasite persistence in the aetiology of Chagas disease. International Fournal for Parasitology 31, 550-554.
Wang, L., Wirp, S. and Duff, H. (2000). Age-dependent response of the electrocardiogram to $\mathrm{K}(+)$ channel blockers in mice. American Fournal of Physiology 278, C73-C78.

World Health Organization (1995). Chagas' disease: important advances in elimination of transmission in four countries in Latin America. WHO Press Office Feature, Geneva, Switzerland. 